Review

\title{
Health benefits and bioactive compounds of eggplant
}

\author{
Nergiz Gürbüz ${ }^{\mathrm{a}, 1}$, Selman Uluişik ${ }^{\mathrm{b}, 1}$, Anne Frary ${ }^{\mathrm{a}}$, Amy Frary ${ }^{\mathrm{c}}$, Sami Doğanlar ${ }^{\mathrm{a}, *}$ \\ a Izmir Institute of Technology, Department of Molecular Biology and Genetics, 35430 Urla Izmir, Turkey \\ ${ }^{\mathrm{b}}$ Mehmet Akif Ersoy University, Burdur Food Agriculture and Livestock Vocational School, 15030 Burdur, Turkey \\ ${ }^{\mathrm{c}}$ Mount Holyoke College, Department of Biological Sciences, The Biochemistry Program, 50 College St, South Hadley, MA 01075, USA
}

\section{A R T I C L E I N F O}

\section{Keywords:}

Metabolic profiling

Solanum melongena

Eggplant

Chemical composition

Bioactive compounds

\begin{abstract}
A B S T R A C T
Eggplant is a vegetable crop that is grown around the world and can provide significant nutritive benefits thanks to its abundance of vitamins, phenolics and antioxidants. In addition, eggplant has potential pharmaceutical uses that are just now becoming recognized. As compared to other crops in the Solanaceae, few studies have investigated eggplant's metabolic profile. Metabolomics and metabolic profiling are important platforms for assessing the chemical composition of plants and breeders are increasingly concerned about the nutritional and health benefits of crops. In this review, the historical background and classification of eggplant are shortly explained; then the beneficial phytochemicals, antioxidant activity and health effects of eggplant are discussed in detail.
\end{abstract}

\section{Introduction}

The primary concern of plant breeders has traditionally been the agronomic properties of crop plants: yield, uniformity and resistance. With population growth, climate change, soil and irrigation management practices all contributing toward a decline in both the quantity and quality of arable land, crop yield and disease resistance continue to be breeding priorities. However, increased consumer awareness of the nutritional and medicinal qualities of fruits and vegetables has shifted some of the breeders' focus toward enhancing the chemical composition of plants (Raigon, Prohens, Muñoz-Falcón, \& Nuez, 2008).

In addition to accumulating minerals that are essential elements in the human diet, plants produce a wide array of both primary and secondary metabolites that impact human health and nutrition. Primary metabolites are compounds that are directly involved in plant physiological and developmental processes. The carbohydrates, proteins, lipids and vitamins, made by plants as primary metabolites, are crucial to human nutrition. Secondary metabolites are not essential for basic plant processes. However, these phytochemicals often play important roles in plant defence against biotic and abiotic stresses. Although there is no common classification of secondary metabolites, generally they can be categorized as phenolics, terpenoids, nitrogen-containing alkaloids and sulfur-containing compounds. In addition, both traditional and modern medicine rely on these phytochemicals as an important source of remedies and pharmaceuticals. Thus, understanding the metabolic constitution of plants and the genetic control of secondary metabolite synthesis is now a goal of many breeding programmes. Such knowledge promises to facilitate strategies for improving traits, such as flavour, and biotic and abiotic stress resistance, and should help to address the more complex issue of modifying levels of antioxidants and amino acids as a means of improving crop compositional quality (Maloney, 2004). Thus, metabolomics approaches are becoming more important in plant breeding.

Metabolomics is the "study of all the chemical compounds in an organism that have low molecular weight" (Maloney, 2004). Liquid chromatography (LC) and gas chromatography (GC) are often combined with mass spectrometry (MS) to reveal the metabolic composition of plants. This strategy is frequently untargetted: although it reveals variation among individual plants, it often does not attempt to identify individual chemical compounds. Metabolic profiling, on the other hand, targets specific metabolites and results in qualitative and quantitative data that can be used for various purposes. Populations can be phenotyped for a specific metabolite, the safety of genetically modified organisms (GMOs) can be more precisely evaluated, and plants can be screened to uncover metabolite bioactivity and to assess metabolites as biomarkers of plant stress, injury or disease. Using metabolites as

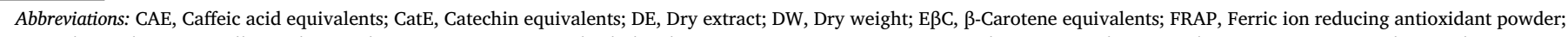

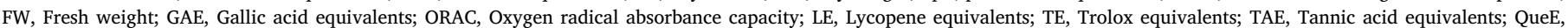
Quercetin equivalents

* Corresponding author.

E-mail addresses: annefrary@iyte.edu.tr (A. Frary), afrary@mtholyoke.edu (A. Frary), samidoganlar@iyte.edu.tr (S. Doğanlar).

${ }^{1}$ Equal contributions. 
biomarkers is challenging. Unlike molecular markers they are subject to environmental variation. However, under controlled environmental conditions, metabolome analyses offer the potential of biomarker discovery and application. These types of studies can help to reveal the quantitative genetic bases of the biochemical processes underlying metabolite production and may inform breeding strategies. For these reasons metabolomics and metabolic profiling are increasingly popular platforms in plant genetics and breeding (Kliebenstein, 2009).

Eggplant (Solanum melongena L.) also known as aubergine, brinjal, berenjena or Guinea is an agronomically and economically important non-tuberous species of the nightshade Solanaceae family. Eggplant has been cultivated for centuries in Asia, Africa, Europe, and the Near East (Bohs \& Weese, 2010). Today, around 50 million tons of cultivated eggplant are produced on more than $1,800,000$ ha worldwide (FAOSTAT, 2014, Accessed 03.08.2017). Eggplant production is concentrated in a few countries: China (29.5 million tons) is the top producer, followed by India (13.5 million tons), Egypt (1.2 million tons), Iran (0.85 million tons) and Turkey ( 0.82 million tons). However, eggplant fruit are also commonly sold in American, European, and Australian markets (FAOSTAT, 2014, Accessed 03.08.2017).

Eggplant is a high-yielding crop and is well-adapted to hot and wet environments. Therefore it typically remains affordable while other vegetable crop prices increase. As a result, eggplant is an especially important source of nutrients (Table 1) in the diets of low-income consumers (Hanson et al., 2006). Interest in this plant is growing rapidly because it is a good source of antioxidants (anthocyanins and phenolic acids), which are beneficial to human health (Gajewski, Katarzyna, \& Bajer, 2009). Eggplant has also been used in traditional medicine to treat many diseases. For example, in parts of Asia, vegetative aerial parts of $S$. americanum/nigrum were traditionally used for treatment of skin problems and as a purgative, to ease urination, and to

Table 1

Nutritional value of eggplant (USDA report 11209).

\begin{tabular}{|c|c|c|}
\hline Nutrient & Unit & Value per $100 \mathrm{~g}$ \\
\hline \multicolumn{3}{|l|}{ Proximates } \\
\hline Water & g & 92.3 \\
\hline Energy & kcal & 25.0 \\
\hline Protein & $\mathrm{g}$ & 0.98 \\
\hline Total lipid (fat) & $\mathrm{g}$ & 0.18 \\
\hline Carbohydrate, by difference & $\mathrm{g}$ & 5.88 \\
\hline Fibre, total dietary & $\mathrm{g}$ & 3.00 \\
\hline Sugars, total & $\mathrm{g}$ & 3.53 \\
\hline \multicolumn{3}{|l|}{ Minerals } \\
\hline Calcium, Ca & $\mathrm{mg}$ & 9.00 \\
\hline Iron, $\mathrm{Fe}$ & $\mathrm{mg}$ & 0.23 \\
\hline Magnesium, Mg & $\mathrm{mg}$ & 14.0 \\
\hline Phosphorus, P & $\mathrm{mg}$ & 24.0 \\
\hline Potassium, K & $\mathrm{mg}$ & 229.0 \\
\hline Sodium, Na & $\mathrm{mg}$ & 2.00 \\
\hline Zinc, Zn & $\mathrm{mg}$ & 0.16 \\
\hline \multicolumn{3}{|l|}{ Vitamins } \\
\hline Vitamin C & $\mathrm{mg}$ & 2.20 \\
\hline Thiamin & $\mathrm{mg}$ & 0.039 \\
\hline Riboflavin & $\mathrm{mg}$ & 0.037 \\
\hline Niacin & $\mathrm{mg}$ & 0.649 \\
\hline Vitamin B6 & $\mathrm{mg}$ & 0.084 \\
\hline Folate, DFE & $\mu \mathrm{g}$ & 22.0 \\
\hline Vitamin B12 & $\mu g$ & 0.00 \\
\hline Vitamin A, RAE & $\mu g$ & 1.00 \\
\hline Vitamin A, IU & $\mathrm{IU}$ & 23.0 \\
\hline Vitamin E ( $\alpha$-tocopherol) & $\mathrm{mg}$ & 0.30 \\
\hline Vitamin D (D2 + D3) & $\mu g$ & 0.00 \\
\hline Vitamin K (Phylloquinone) & $\mu \mathrm{g}$ & 3.50 \\
\hline \multicolumn{3}{|l|}{ Lipids } \\
\hline Fatty acids, total saturated & $\mathrm{g}$ & 0.034 \\
\hline Fatty acids, total monosaturated & $\mathrm{g}$ & 0.016 \\
\hline Fatty acids, total polysaturated & $\mathrm{g}$ & 0.076 \\
\hline Cholesterol & $\mathrm{mg}$ & 0.000 \\
\hline
\end{tabular}

increase sex drive (Meyer, Bamshad, Fuller, \& Litt, 2014). In the same study, 77 medicinal properties were recorded for eggplant which indicates the importance of this plant in local medicine and its promise as a functional food and in the natural products industry.

Although there are a few reviews describing the structures and levels of phenolic compounds in eggplant, there is no collective information in the form of a literature review that summarizes the nutritional and phytochemical compounds in eggplant, their antioxidative potential and health benefits. This review aims to shed light on the nutritional content and potential pharmaceutical benefits of different eggplant species. This information can help to determine which properties warrant further breeding efforts.

\section{Background and classification of eggplant}

Eggplant is an Old World species, unlike other solanaceous crops which are native to the New World. However, like its Solanum relatives, tomato and pepper, eggplant is an autogamous diploid with 12 chromosomes $(2 n=24)$. The fruit of the eggplant is botanically classified as a berry, and contains numerous edible soft seeds that are bitter because they contain nicotinoid alkaloids. Although the domestication history of eggplant has long been debated, according to the most accepted hypotheses, eggplants were first domesticated over 4000 years ago in south east Asia (Meyer, Karol, Little, Nee, \& Litt, 2012). The putative progenitor of eggplant, $S$. insanum L. is widespread in tropical Asia from Madagascar to the Philippines (Syfert et al., 2016). India has been labelled the centre of diversity of varietal eggplant by some researchers (Fraikue, 2016). Cultivation of this crop then spread through Africa, the Near East and Europe.

Although there are several different eggplant species grown around the world, the one most commonly cultivated is Solanum melongena. Wild relatives of this eggplant species produce large spiny leaves and small, green, hard, egg-shaped fruits. S. melongena differs from its wild predecessors mostly in terms of fruit colour and shape. Ranging from dark purple to black, with some green and white varieties, the fruit of cultivated eggplant is larger than the wild type and more variable in shape. Some eggplant varieties have rounder (S. melongena var. esculentum) fruits whereas others have elongated ( $S$. melongena var. serpentinum) fruits (Swarup, 1995). Two other agriculturally important species of eggplant are commonly grown and consumed in Africa: Solanum aethiopicum and Solanum macrocarpon. Unlike $S$. melongena, these species are grown for their nutritious leaves. S. aethiopicum is a shrublike plant with hairy or glabrous leaves. Based on leaf and fruit morphology and uses, S. aethiopicum is grouped into four accessions (Aculeatum, Gilo, Kumba, and Shum). The Gilo group is the most important group in the $S$. aethiopicum complex with its large and rounded edible fruits (Gramazio et al., 2016). S. macrocarpon is grown solely for its large, glabrous leaves. It produces small yellow-orange fruits which are not edible (Macha, 2005).

\section{Bioactive compounds in eggplant}

\subsection{General}

Plant secondary metabolites are not essential for basic plant processes; however, traditional and modern medicine rely on these bioactive compounds which, with their antioxidant properties, are an important source of remedies and pharmaceuticals. Phenolics and carotenoids are the main phytochemicals that help maintain human health (Singh, Kaur, Shevkani, \& Singh, 2015). Like other vegetables and fruits, eggplants have a characteristic array of bioactive compounds, including phenolics, carotenoids and alkaloids. The following sections concentrate on the beneficial phytochemicals present in eggplant. 


\subsection{Phenolic compounds}

Eggplant is considered to be the best source of total phenolic acids within cultivated members of the Solanaceae (Helmja, Vaher, Gorbatšova, \& Kaljurand, 2007). Several studies have shown that eggplant has a diverse phenolic content with significant variability among eggplant lines (Chumyam, Whangchai, Jungklang, Faiyue, \& Saengnil, 2013; Kaur, Nagal, Nishad, Kumar, \& Sarika, 2014; Mennella et al., 2012; Prohens et al., 2013; Okmen et al., 2009). The total phenolic content (ranging from $23 \mathrm{mg} / 100 \mathrm{~g}$ DW to $1,168,100 \mathrm{mg} / 100 \mathrm{~g} \mathrm{DW}$ ) of eggplant cultivars and wild relatives is presented in Table S1 which also includes some other major phenolic acids, flavonoids and tannins identified by various researchers. Harvesting season has an effect on phenolic acid content in eggplant (García-Salas, Gómez-Caravaca, Gómez-Caravaca, Segura-Carretero, \& Fernández Gutiérrez, 2014). Most of the phenolic compounds decreased from spring to summer, suggesting that high temperatures have a negative effect on phenolic content. This information might be a guide for the agricultural sector in determining a suitable time for harvesting eggplants with high phenolic compound content.

Supplementary data associated with this article can be found, in the online version, at https://doi.org/10.1016/j.foodchem.2018.06.093.

Evidence suggests that the phenolic acid and tannin contents of eggplant's wild relatives and landraces are even higher than that of cultivars (Kaur et al., 2014; Ossamulu, Akanya, Jigam, \& Egwim, 2014; Prohens, Burruezo, Raigon, \& Nuez, 2007; Prohens et al., 2013; Raigon, Rodriguez-Burruezo, \& Prohens, 2010). The wild relative $S$. incanum has more total phenolic compounds than $S$. melongena; however, there are no significant differences between the phenolic acid profiles of wild type and those of cultivated eggplant (Raigon et al., 2008). S. incanum has recently been used in breeding programmes to improve the phenolic acid content of commercial eggplant lines (Prohens et al., 2013). Landraces represent another useful source of variation which can help selection and breeding programmes. Despite the antioxidant benefits of phenolics for the plant and human consumers, it is important to recognize that high phenolic acid content also brings some disadvantages, such as accelerated fruit browning (Tan, Kha, Parks, \& Roach, 2016).

Browning of fruits and vegetables is a major problem in the food industry as it is one of the greatest causes of quality loss during postharvest and processing. In general, browning is caused by enzymatic oxidation of phenolic compounds and polyphenol oxidase (PPO) is the main enzyme in this degradation. Peroxidase (POD) activity can also cause browning but is a less significant contributor than PPO (Mishra, Gautam, \& Sharma, 2013). Several studies have characterized PPO activity in different eggplant cultivars in different environments. However, the main focus is on reducing the level of browning by different methods. For example, browning was significantly inhibited by cutting, using a thin, sharp blade, and immediate dipping in water for $10 \mathrm{~min}$, followed by ambient air-drying and packaging. Because, such cutting caused less physical injury and cell death, it resulted in reduced leaching of phenolics and polyphenol oxidase activity and hence less browning (Mishra, Gautam, \& Sharma, 2012). In other work carried out by Dogan, Arslan \& Dogan (2002), PPO enzyme activity for three eggplant cultivars decreased with increasing temperature and inactivation time, and showed very little activity at about $60^{\circ} \mathrm{C}$.

Flavonoids are significant phenolic compounds in eggplant. Eggplant leaves and fruits have different flavonoid profiles. While kaempferol, quercetin, apigenin and isorhamnetin are minor compounds in eggplant fruit (Huang, Wang, Eaves, Shikany \& Pace, 2007), kaempferol accumulates in the leaves (Piao et al., 2014). Solanum anguivi, African eggplant, might be an exception as it had high levels of some flavonoids, such as rutin and quercetin (Elekofehinti et al., 2013). This result might suggest that other eggplant species should be explored for potentially high levels of flavonoids. Although tannins are one of the major groups of flavonoids, there are not many reports on tannin content in the eggplant literature. Alkurd, Takruri \& Al-Sayyed (2008) (a)<smiles>O=C(/C=C\c1ccc(O)c(O)c1)O[C@H]1C[C@H]2[C@@H](O)C(O)CC(O)(C1)C2(O)C(=O)O</smiles>

(b)

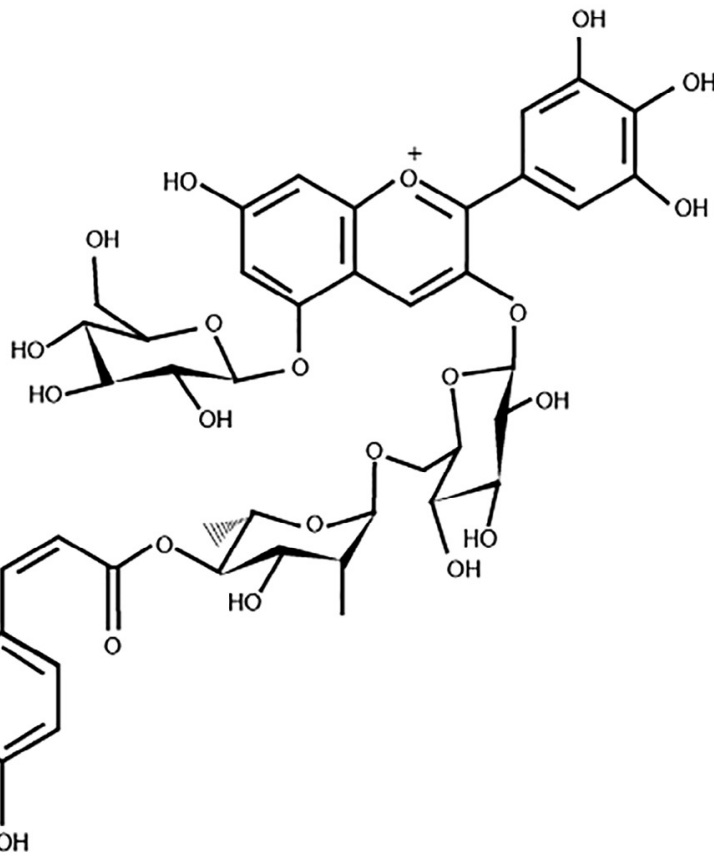

Fig. 1. Chemical structures of phenolic acids, (a) chlorogenic acid, (b) nasunin.

measured tannin content in 39 plants used in the Jordanian diet and found that eggplant had nearly two-fold more tannins than had tomato.

Hydroxycinnamic acids (HCA) and their derivatives are the most prevalent class of phenolic acid conjugates in eggplant $(8.6-13.6 \%$ of the total phenolic acid conjugates) (Stommel, Whitaker, Haynes \& Prohens, 2015), and there are significant differences in individual HCA profiles among eggplant cultivars (Whitaker \& Stommel, 2003). Chlorogenic acid (CGA) (Fig. 1a), an ester of HCA, is the single most abundant phenolic compound in eggplant (ranging from 4240 to 9610 mg/kg) (Medina, Orona, Rangel \& Heredia, 2017; Plazas, Andujar et al., 2013; Whitaker \& Stommel, 2003). Caffeoylquinic acid (CQA) derivatives show high antioxidant capacity and are found in high concentrations in eggplant and related Solanum species (Whitaker \& Stommel, 2003). The content of potentially health beneficial HCA conjugates is substantial in eggplant cultivars. The data on HCA conjugates will help in development of new cultivars with optimal HCA composition and content.

Anthocyanins are naturally occurring pigments in eggplant. They are concentrated in the fruit peel, ranging from 80 to $850 \mathrm{mg} / \mathrm{kg}$ peel with variability due to agronomic and genetic factors, intensity and type of light, temperature, processing and storage (Dranca \& Oroian, 2016). Delphinidin glucosides (derivatives of delphinidin anthocyanidin) are one of the major anthocyanins of eggplant peel and impart a dark purple colour (Li \& Ding, 2012; García-Salas et al., 2014). Acylglycosides (for example nasunin shown in Fig. 1b) have also been identified in Japanese eggplant varieties (Casati, Pagani, Braga, Scalzo \& Sibilia, 2016).

Consumers generally feel that organic foods are healthier and more nutritious. Metabolomics have been used to test this notion. Organically 
(a)<smiles>CC1=CC(O)CC(C)(C)C1/C=C/C(C)=C/C=C/C(C)=C/C=C/C=C(C)/C=C/C=C(C)/C=C/C1=C(C)CC(O)CC1(C)C</smiles>

(b)<smiles>CC1=C(/C=C/C(C)=C/C=C/C(C)=C/C=C/C=C(C)/C=C/C=C(C)/C=C/C2=C(C)C[C@@H](O)CC2(C)C)C(C)(C)C[C@H](O)C1</smiles>

Fig. 2. Chemical structures of eggplant carotenoids, (a) lutein, (b) zeaxanthin.

grown eggplants were found to have higher levels of total phenolics $(498 \mathrm{mg} / \mathrm{kg})$ than conventionally grown $(382 \mathrm{mg} / \mathrm{kg})$ eggplants (Raigon et al., 2010). However, fruit of the American variety 'Blackbell', grown under organic and conventional conditions, had nearly identical phenolic contents ( 8900 and $9900 \mathrm{mg} / \mathrm{kg}$, respectively) (Luthria et al., 2010). These results show that the amount of phenolic compounds depends more on the cultivar than on growing conditions. In other work, conventional (50 mg CatE/ $100 \mathrm{~g}$ ) and organic (49 $\mathrm{mg}$ CatE/100 g) cultivation did not have a significant effect on flavonoid content (Zambrano-Moreno, Chávez-Jáuregui, Plaza, \& Beaver, 2015).

\subsection{Carotenoids}

Carotenoids are lipophilic molecules and mostly found in yellowand orange-coloured vegetables and fruits. Carotenoids serve as accessory pigments in photosynthesis and also protect the photosynthetic apparatus from excess energy (Ahmed et al., 2014). These pigments are important in the food industry as colorants and their health benefits

(a)

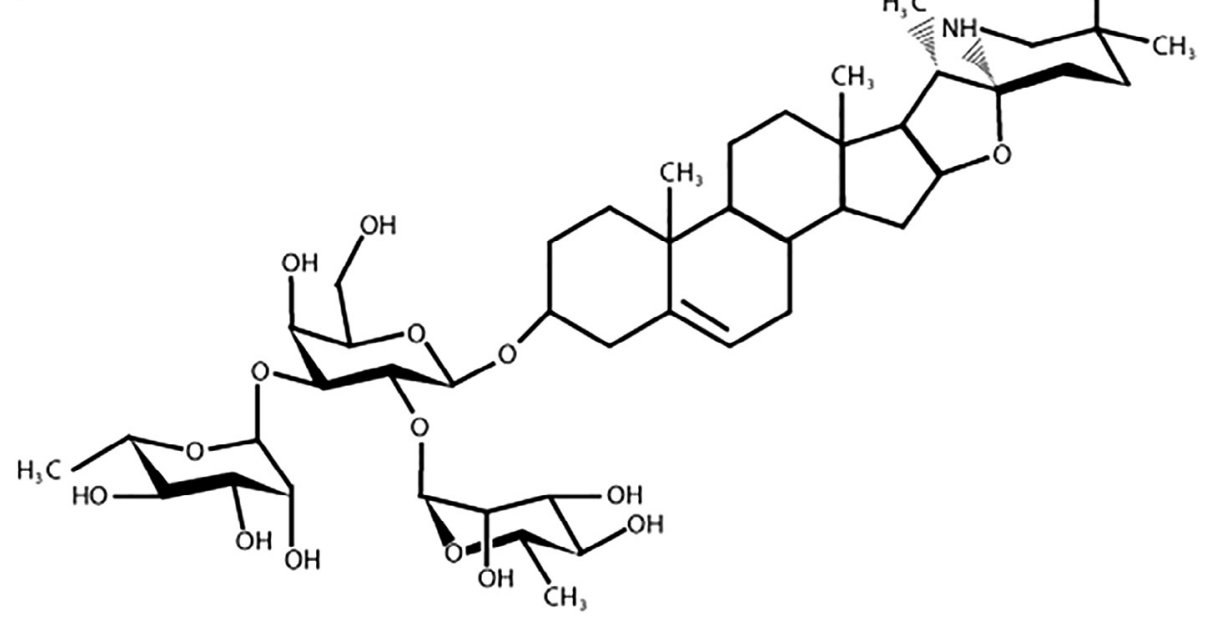

(b)

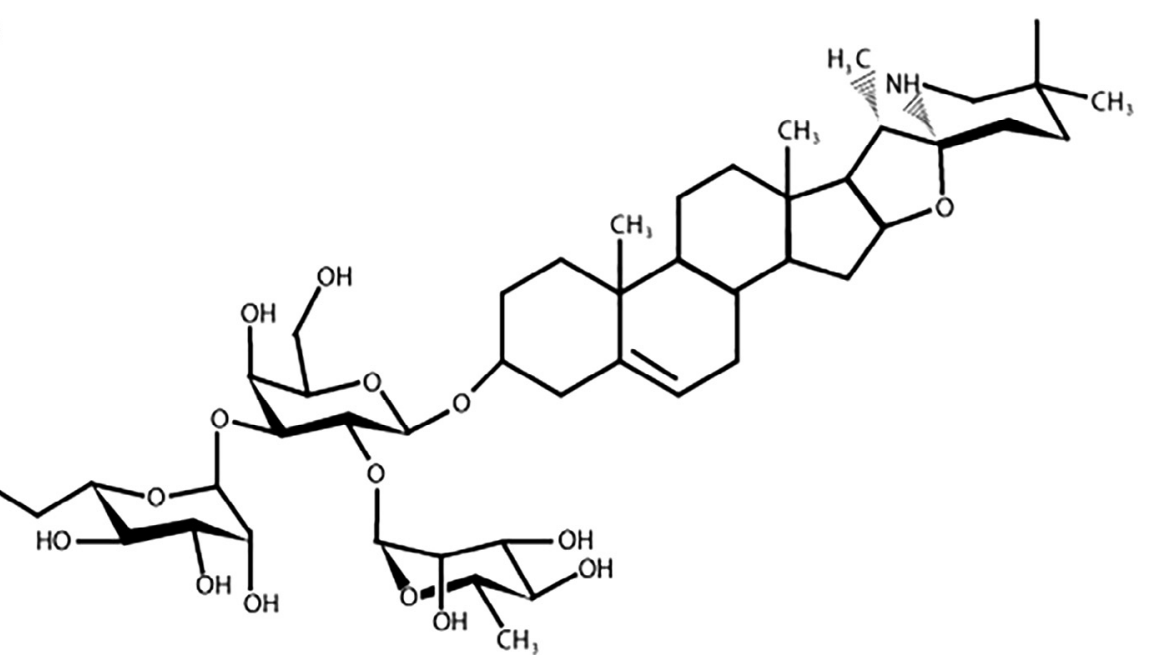

Fig. 3. Chemical structures of eggplant glycoalkaloid, (a) $\alpha$-solamargine, (b) $\alpha$-solasonine. 
have made them popular as dietary supplements. Lutein (Fig. 2a) and zeaxanthin (Fig. 2b) have displayed beneficial effects on age-related macular degeneration (Benke, \& Benke, 2014) and cataracts (Weikel, Garber, Baburins, \& Taylor, 2014). Although eggplant contains lower levels of carotenoids than do some other vegetables, such as carrot and tomato, some locally grown varieties of eggplant can have significant amounts of carotenoids. For example, the best source of lutein and zeaxanthin in vegetables and vegetable oils commonly consumed in India is pumpkin, followed by chili and eggplant (Aruna, Mamatha, \& Baskaran, 2009). The carotenoid contents reported in some eggplant species and cultivars are presented in Table S2.

Carotenoid levels are affected by various factors, such as developmental stage of the plant, stress conditions, post-harvest conditions or cooking treatments. Carotenoid levels are highest at early stages of eggplant fruit maturity, then decrease during eggplant fruit ripening, and post-harvest storage at $0{ }^{\circ} \mathrm{C}$ protects carotenoid levels (Zaro, Keunchkarian, Chaves, Vicente, \& Concellón, 2014). Heat treatment (cooking, grilling and frying) decreases carotenoid levels (ArkoubDjermoune et al., 2016; Das et al., 2011). The effect of drought stress on carotenoid profiles depends on the type of carotenoid. While carotenes, chlorophylls, neoxanthin and violaxanthin contents declined, the amount of zeaxanthin increased under stress conditions (Mibei, Ambuko, Giovannoni, Onyango \& Owino, 2017). There is growing interest in carotenoids because of their potential as antioxidants to decrease the risk of certain cancers. Thus, metabolomic approaches are necessary to expose the potential of eggplant carotenoids in different varieties.

\subsection{Glycoalkaloids}

Glycoalkaloids are nitrogen-containing steroidal glycosides found in members of the genus Solanum, including the crop species potato ( $S$. tuberosum), tomato ( $S$. lycopersicum) and eggplants ( $S$. melongena, $S$. macrocarpon and $S$. aethiopicum). Glycoalkaloids have roles in plant resistance against pests and pathogens (Sanchez-Maldonado, Schieber \& Gänzle, 2016). Two main steroidal glycoalklaoids (SGAs) found in eggplant are $\alpha$-solamargine (Fig. 3a) and $\alpha$-solasonine (Fig. 3b) (Blankemeyer, McWilliams, Rayburn, Weissenberg, \& Friedman, 1998). These SGAs have potential to treat different types of cancers, such as gastric cancer (Ding, Zhu, Yang \& Li, 2013), leukemia (Sun et al., 2011), liver cancer (Ding, Zhu, Li, \& Gao, 2012), lung cancer (Liu et al., 2004), osteosarcoma (Li et al., 2011) and basal cell carcinoma (Punjabi, Cook, Kersey, Marks, \& Cerio, 2008). In addition to the anticarcinogenic effect, their antiparasitic activity was reported in the literature. Researchers showed that SGAs have an antiparasitic effect on Leishmania mexicana (Lezama-Dávila et al., 2016), Leishmania amazonensis (Miranda et al., 2013) and Trypanosoma cruzi (Hall, Hobby \& Cipollini, 2006; Chataing, Concepción, Lobatón, \& Usubillaga, 1998). Although they have beneficial effects, glycoalkaloids are toxic to humans and can even cause death at high concentrations ( $3-5 \mathrm{mg} / \mathrm{kg}$ body mass) (Bagheri, Bushehri, Hassandokht \& Naghavi, 2017). Market eggplant, $S$. melongena, has lower levels of glycoalkaloids than the toxic dose (Table S3). Levels in $S$. aethiopicum were similar to those of $S$. melongena and thus safe for consumption. On the other hand, glycoalkaloid levels in fruit flesh of $S$. macrocarpon were 5-10 times higher than the value considered as safe in foods (Sanchez-Mata, Yokoyama, Hong, \& Prohens, 2010).

Glycoalkaloids are found at different concentrations in different parts of the plants and at different developmental stages as is the case with different wild relatives and varieties of eggplant. The highest solasodine content was observed in flower buds, followed by leaf, physiologically ripe fruit, young fruit, and mature fruit (Bagheri et al., 2017). It is well known that glycoalkaloids are effective inhibitors of cancer cells due to their toxic effects. However, the optimal levels for toxicity should be further studied.

\section{Antioxidant capacity of eggplant}

Metabolic processes are necessary for the continuity of life. However, these processes produce potentially dangerous entities called reactive oxygen species (ROS). The primary source of ROS is incompletely processed oxygen or electrons produced by the electron transport chain (ETC) in the mitochondria (Elekofehinti et al., 2013). The free radical groups of ROS are highly reactive and disrupt the chemical bonds of nearby molecules. For this reason, ROS are usually neutralized or recycled immediately after they are produced. This function is generally performed by antioxidants (Akanitapichat, Phraibung, Nuchklang, \& Prompitakkul, 2010). If ROS are not neutralized, proteins, lipids and DNA molecules can be damaged. This damage has been linked to cancer, as well as neurodegenerative and cardiovascular diseases. In addition, because the liver functions as a recycling centre for these reactive species, liver diseases have been associated with ROS (Cichoż-Lach \& Michalak, 2014).

Humans can synthesize antioxidant enzymes, yet levels of these enzymes are not high enough to cope with the ROS generated by metabolic processes within the cells. For this reason, dietary sources of antioxidants are required (Lobo, Phatak, \& Chandra, 2010). Plants can synthesize a variety of antioxidants, and many plants are rich in such compounds. The antioxidant capacity of eggplant is ranked in the top ten of 120 different vegetables (Nisha, Nazar, \& Jayamurthy, 2009). However, the total amount of these compounds varies (ranging from 2664 to $8247 \mathrm{mmol}$ trolox $/ \mathrm{kg}$ ) according to eggplant variety, fruit shape and size and methodology. For example, antioxidant activity in five types of eggplant (Chinese, Philippine, American Hindu, and Thai) ranged from 95 to $539 \mu \mathrm{mol} \mathrm{TE} / g$ (Medina et al., 2014). A long eggplant cultivar had the third highest antioxidant activity in FRAP (5.31-8.66 mmol eq. $\mathrm{FeSO}_{4} / 100 \mathrm{~g}$ ); however, the same eggplant cultivar showed the second-lowest antioxidant capacity in the ORAC assay (0.383-0.594 mmol TE/100 g) among 44 fruits and vegetables grown in Andalucia (Morales-Soto et al., 2014). The skin of eggplant fruit shows particularly high superoxide-scavenging (SOS) activity in inhibiting hydroxyl radical generation (Kaneyuki, Noda, Traber, Mori, \& Packer, 1999). Anthocyanin extracts have the greatest reducing power and SOS activity while phenolic extracts show the greatest metal-chelating activity (Boulekbache-Makhlouf, Medouni, Medouni-Adrar, Arkoub, \& Madani, 2013).

Antioxidant capacity and phenolic acid content are highly positively correlated in eggplant (Chumyam et al., 2013; Okmen et al., 2009; Plazas, Lopez-Gresa et al., 2013). Moreover, antioxidant capacity is related to skin colour and fruit size. Small purple fruit showed higher phenolic and anthocyanin contents and higher antioxidant capacity than did other eggplant fruit types (long green, large purple, mediumsized purple) (Nisha et al., 2009).

Storage and cooking temperatures can have significant effects on the levels of antioxidants in food. The antioxidant content of eggplant fruit increased during the first three days of storage at $0{ }^{\circ} \mathrm{C}$ and then declined. In contrast, a gradual and continuous accumulation was observed at $10^{\circ} \mathrm{C}$ (Concellón, Zaro, Chaves, \& Vicente, 2012). Refrigerated storage $\left(4^{\circ} \mathrm{C}\right)$ did not cause loss of antioxidant activity (Murcia, Jiménez, \& Martínez-Tomé, 2009). Heat treatment, such as cooking, led to higher total phenolic content and antioxidant capacity as compared to raw eggplant (Ramírez-Anaya, Samaniego-Sánchez, Castañeda-Saucedo, Villalón-Mir, \& Serrana, 2015, Chumyam et al., 2013). The antioxidant activity of eggplant decreased in response to grilling below $65^{\circ} \mathrm{C}$ but increased after grilling at higher temperatures up to $95^{\circ} \mathrm{C}$ (Uchida, Tomita, Takemori, \& Takamura, 2017). However, not all cooking methods increase the antioxidant capacity of the eggplant. Frying caused $50 \%$ losses in antioxidant activity (Kalkan \& Yücecan, 2013).

Deep-fat frying is an extensively used cooking method that enhances organoleptic properties but reduces nutritional value and compromises the antioxidant content of foods. Oxidation, hydrolysis, polymerization, 
Table 2

Uses and health benefits of eggplant bioactive compounds.

\begin{tabular}{|c|c|c|}
\hline Compound & Use and Health Benefits & Reference \\
\hline Delphinidins & Significantly reduce oxidative stress and blood glucose, counteract vascular inflammation & Watson and Schönlau (2015) \\
\hline Kaempferol & Antioxidant defence against free radicals, reduces the risk of chronic diseases, especially cancer. & Chen and Chen (2013) \\
\hline Myricetin & $\begin{array}{l}\text { Antioxidative and cytoprotective effects, anti-carcinogenic actions, antiviral, antimicrobial properties, and anti- } \\
\text { platelet activity }\end{array}$ & Li and Ding (2012) \\
\hline Quercetin & $\begin{array}{l}\text { Antioxidant, improves normal cell survival, antiviral, anti-inflammatory, antibacterial, and muscle-relaxing } \\
\text { properties }\end{array}$ & $\begin{array}{l}\text { Jan, Kamli, Murtaza, Singh, and Ali } \\
\text { (2010) }\end{array}$ \\
\hline Luteolin & $\begin{array}{l}\text { Biological and pharmacological activities, including antioxidant, anti-inflammatory, potentially useful in } \\
\text { treating atherosclerosis }\end{array}$ & Jiang, Li, and $\mathrm{Wu}(2013)$ \\
\hline Isorhamnetin & $\begin{array}{l}\text { Intermediate of quercetin, antioxidant and antitumor activity on human hepatocellular cancer cells, prevents } \\
\text { endothelial cell injuries caused by oxidized low-density lipoprotein }\end{array}$ & Jaramillo et al. (2010) \\
\hline Chlorogenic Acid & Antioxidant, anti-inflammatory, cardioprotective, anti-obesity, anti -carcinogenic, and anti-diabetic properties & Plazas, Andujar et al. (2013) \\
\hline Lutein & $\begin{array}{l}\text { Non-provitamin A carotenoid, antioxidant in the retina, protecting the eye from inflammation and oxidative } \\
\text { stress }\end{array}$ & van Lent et al. (2016) \\
\hline Zeaxanthin & $\begin{array}{l}\text { Strong antioxidant and pro-oxidant behaviour as well as anti-inflammatory effects, suppresses oxidative stress in } \\
\text { the retinal tissue }\end{array}$ & Manikandan et al. (2016) \\
\hline B-Cryptoxanthin & $\begin{array}{l}\text { Precursor of vitamin A, may help prevent free radical damage to biomolecules, prevention and treatment of } \\
\text { certain cancers }\end{array}$ & Lorenzo et al. (2009) \\
\hline Tannins & Enhance glucose uptake and inhibit adipogenesis. inhibit oxidation of LDL-cholesterol & Kumari and Jain (2012) \\
\hline Hydroxycinnamic Acids & Antioxidant and free radical-scavenging properties, protect from side effects of chemotherapy & El-Seedi et al. (2012) \\
\hline
\end{tabular}

isomerization and cyclization reactions occur in the oil during the frying process. Synthetic antioxidants, such as butylated hydroxyl anisole, are added to edible oils to improve their oxidative stability but these compounds may have toxic and carcinogenic effects. However, natural antioxidants released during cooking can help protect the oil from lipid oxidation. Thus, eggplant has been investigated as a source of natural antioxidants for extending the usability of frying oil. The high polyphenol content of eggplant peel juice helped to enhance the oxidative stability of frying oil (Basuny, Arafat, \& Kamel, 2013).

\section{Health benefits of eggplant}

Besides its agricultural and nutritional importance, eggplant has a number of medicinal benefits (Table 2). In several studies, extracts from eggplant fruits were shown to have excellent therapeutic effects on warts, burns, and many inflammatory diseases, such as stomatitis, arthritis, and gastritis (Im et al., 2016). The wide range of secondary metabolites produced by eggplant, including antioxidant compounds, glycoalkaloids and vitamins, seems to be the source of many of its health benefits. For example, the phenolic compound chlorogenic acid (5-O-caffeoyl-quinic acid; CGA), a major phenolic compound in the fruit flesh (Prohens et al., 2013), provides many benefits for human health, such as antioxidant, anti-inflammatory, cardioprotective, antiobesity, and anti-diabetic properties (Plazas, Andujar et al., 2013; Plazas, Lopez-Gresa et al., 2013). CGA also demonstrates anti-carcinogenic effects by inducing apoptosis in many human cancer cells, such as leukemia and lung cancer cells (Tajik, Tajik, Mack \& Enck, 2017). Afshari et al. (2016) demonstrated that an eggplant extract had a more toxic effect on cancer cells than on normal cells. The antibacterial properties of methanolic extracts of eggplant fruits have been tested and shown to be effective against $S$. aureus, V. cholera, B. subtilis, $B$. cereus, E. coli and Pseudomonas sp. (Ahmed, Mubassara \& Sultana, 2016). Although the results are promising, more studies are needed on the bioactive compounds of eggplant extracts and their possible mechanisms of action against cancer cells.

Anthocyanins have long been valued for their colouring properties; however, their roles in helping to prevent neuronal diseases, cardiovascular illnesses, cancer, diabetes, inflammation, and many other medical conditions are now becoming clear. The health-promoting effects of anthocyanins are mostly related to their antioxidant activity. Different anthocyanins have shown high antioxidant activity by in vitro and in vivo tests. It is known that high iron levels in cells cause lipid peroxidation. Consuming purple eggplant, which has a high level of the antioxidant nasunin (the major anthocyanin in eggplant skin), can help prevent lipid peroxidation and ROS accumulation (Casati et al., 2016). Anthocyanins appear to increase serum antioxidant capacity and help prevent cardiovascular disease and hyperlipidemia by reducing LDL (low density lipoprotein) oxidation. Basuny, Arafat \& El-Marzooq (2012) claimed that eggplant peel can be used in pharmaceuticals because of the reducing power of anthocyanins on cholesterol levels. Anthocyanins also seem to have antiangiogenic activities (Matsubara, Kaneyuki, Miyake \& Mori, 2005) and help prevent inflammation by inhibiting cyclooxygenases (COXs) (Lin \& Li, 2017). Antiproliferative, apoptotic, anti-inflammatory, antioxidant and antimutagenic effects have also been observed in anthocyanin-treated gastrointestinal cancer cells (Wang \& Stoner, 2008). When added to the diet, anthocyanins seem to have a role in preventing obesity by reducing serum triglyceride and cholesterol and increasing high-density lipoprotein (HDL) cholesterol (Seeram, Momin, Nair \& Bourquin, 2001). Moreover, they appear to control diabetes, are used in ulcer treatment, and help improve cognitive function (Yousuf, Gul, Wani \& Singh, 2016) and eyesight (Ghosh \& Konishi, 2007). Thus eggplant phytochemicals may be a potential source of antimicrobial agents as well as natural antioxidants.

As humans cannot synthesize carotenoids, they need to include them in their diet. Consumption of carotenoid-rich foods has been associated with a decreased risk of several types of cancer (LinnewielHermoni et al., 2015). Lutein, zeaxanthin and $\beta$-cryptoxanthin have shown beneficial effects on age-related muscular degeneration (Benke \& Benke, 2014), cataracts (Weikel et al., 2014), reducing cardiovascular disease (Pietro, Tomo \& Pandolfi, 2016) and protecting against sunburn-related disorders (Cooperstone \& Schwartz, 2016). Vitamin A deficiency is an important problem for school children in some countries. The introduction of carotenoid-rich eggplant in the diet of children could help in reducing this problem (Kamga, Kouame, Atangana, \& Chagomoka, \& Ndango, 2013).

Glycoalkaloids are reported to possess anti-cancer activity. Solasodine, a naturally occurring aglycone of the glycoalkaloid in eggplant, reduces human lung cancer cells in vitro (Shen et al., 2017). Glycoalkaloids also have anti-inflammatory (Ferreira da Costa et al., 2015) properties, and have been used to help lower blood cholesterol (Friedman, 2006). Overall, glycoalkaloids seem to be a natural product that can be used in the fight against cancer cells. However, more research at the molecular level needs to be done.

The fibre content of eggplant promotes healthy digestion, which helps the body get rid of waste materials and harmful toxins, thereby reducing the risk of colon and stomach cancer (Fraikue, 2016). Eggplant's high fibre and low soluble carbohydrate levels make it a good choice for helping to manage type 2 diabetes (Nwanna, Ibukun \& Oboh, 
2013). African eggplant (Solanum kumba) was found to reduce blood glucose levels in diabetic rats. These results suggest that a diet rich in eggplant may be a good way to reduce hyperglycemia, hypertension and oxidative stress in those with type 2 diabetes (Nwanna, Ibukun \& Oboh, 2016).

Hyperlipidemia and obesity can cause a variety of serious diseases. A diet rich in products, aiding in lipid digestion and absorption inhibitory activities, may be beneficial for human health. Feeding albino rats with dried eggplant was effective in lowering hypercholesterolemia (Hussein, 2012). Green eggplant juice (Solanum aculeatissimum Jacq.) was the most effective disruptor of micellar cholesterol which effectively inhibits cholesterol solubility (Trisat, Wong, Lapphanichayakool, Tiyaboonchai, \& Limpeanchob, 2017).

Health-conscious consumers generally focus on the antioxidant, phenolic and vitamin contents of foods. However, carbohydrates are an indispensable part of the human diet and possess more health benefits than they are generally given credit for. Polysaccharides have beneficial biological activities, such as immunomodulation, antitumor effects and antioxidant properties (Mei, Yi \& Huang, 2017). Saccharides (such as glucose, fructose, saccarose), sugar alcohols (e.g. sorbitol, mannitol, inositol, myoinositol), and $\beta$-galactosides (e.g. raffinose, stachyose, and galactosyl-cyclitols) are low molecular weight carbohydrates important in nutrition. Eggplant is rich in saccharides, such as fructose $(13750 \mathrm{mg} / \mathrm{kg})$, glucose $(13270 \mathrm{mg} / \mathrm{kg}$ ) and, to a lesser extent sucrose (5030 mg/kg) (Ayaz et al., 2015). S. melongena also contains inositol and its derivatives which have positive effects on human health, including the treatment of insulin resistance (Michell, 2007). A molecule with therapeutic properties against Alzheimer's disease pathologies, scyllo-inositol $(16 \mathrm{mg} / \mathrm{kg})$, was also reported to be present in eggplant (Hernandez-Hernandez, Ruiz-Aceituno, Sanz \& Martínez-Castro, 2011). Mannitol, another carbohydrate with various physiological properties within the cell, was found in low amounts in the same analysis. As mentioned above, although carbohydrates constitute a major part of the human diet, they have not been researched in detail, especially in eggplant. Therefore, both simple sugar and polysaccharide levels in different varieties of eggplant should be studied further.

\section{Conclusion and future perspectives}

Metabolomics and metabolic profiling are powerful techniques for evaluating the biochemical and nutritional composition of plants. Many bioactive compounds have not yet been discovered and adequately characterized. Analytical tools and platforms, such as metabolomics and metabolic profiling, have developed considerably, leading to the discovery of various bioactive compounds and characterization of their bioactivity in a less time-consuming and less laborious way. Exploration of the plant world for bioactive compounds can be used to develop pharmaceutical and agricultural products. Thus, metabolomics can help inform breeding programmes aimed at improving crop quality. In the Solanaceae family there have been numerous studies of metabolites in tomato and potato. Although eggplant is an important source of nutraceuticals and pharmaceuticals, few studies have investigated compounds in eggplant beyond phenolic acids and antioxidant capacity. Moreover, primary metabolites, such as carbohydrates and amino acids, have been largely ignored. Needless to say, eggplant cultivars containing high levels of the aforementioned bioactive compounds should be identified and more work should be done to understand the nutritional and pharmaceutical value of eggplant. New breeding priorities and strategies can then be developed for this valuable vegetable crop.

\section{Acknowledgements}

Special thanks go to Hatice Selale, Cantug Bar for contributions and to Onur Colak for drawing the chemical structures of the metabolites using Adobe Illustrator CC 2018 Software program.

\section{Declaration of conflicting interest}

The authors declare that they have no conflict of interest.

\section{References}

Afshari, F., Serah, H., Hashemi, Z. S., Timajchi, M., Olamafar, E., Ghotbi, L., \& Ganjibakhsh, M. (2016). The cytotoxic effects of eggplant peel extract on human gastric adenocarcinoma cells and normal cells. Modern Medical Laboratory Journal, 1, $42-48$.

Ahmed, F., Fanning, K., Netzel, M., Turner, W., Li, Y., \& Schenk, P. M. (2014). Profiling of carotenoids and antioxidant capacity of microalgae from subtropical coastal and brackish waters. Food Chemistry, 165, 300-306.

Ahmed, F. A., Mubassara, S., \& Sultana, T. (2016). Phytoconstituents, bioactivity and antioxidant potential of some commercial brinjal (Solanum melongena L.) cultivars of Bangladesh. Jahangirnagar University Journal of Biological Sciences, 5, 41-50.

Akanitapichat, P., Phraibung, K., Nuchklang, K., \& Prompitakkul, S. (2010). Antioxidant and hepatoprotective activities of five eggplant varieties. Food and Chemical Toxicology, 48, 3017-3021.

Alkurd, R. A., Takruri, H. R., \& Al-Sayyed, H. (2008). Tannin contents of selected plants used in Jordan. Jordan Journal of Agricultural Sciences, 4, 265.

Arkoub-Djermoune, L. A., Makhlouf, L. B., Hamri, S. Z., Bellili, S., Boukhalfa, F., \& Madani, K. (2016). Influence of the thermal processing on the physico-chemical properties and the antioxidant activity of a Solanaceae vegetable: Eggplant. Journal of Food Quality, 39, 181-191.

Aruna, G., Mamatha, B. S., \& Baskaran, V. (2009). Lutein content of selected Indian vegetables and vegetable oils determined by HPLC. Journal of Food Composition and Analysis, 22, 632-636.

Ayaz, F. A., Colak, N., Topuz, M., Tarkowski, P., Jaworek, P., Seiler, G., \& Inceer, H. (2015). Comparison of nutrient content in fruit of commercial cultivars of eggplant (Solanum melongena L.). Polish Journal of Food and Nutrition Sciences, 65, 251-259.

Bagheri, M., Bushehri, A. A. S., Hassandokht, M. R., \& Naghavi, M. R. (2017). Evaluation of solasonine content and expression patterns of SGT1 gene in different tissues of two Iranian eggplant (Solanum melongena L.) genotypes. Food Technology and Biotechnology, 55, 236-242.

Basuny, A. M. M., Arafat, S. M., \& El-Marzooq, M. A. (2012). Antioxidant and antihyperlipidemic activities of anthocyanins from eggplant peels. Journal of Pharma Research Reviews, 2, 50-57.

Basuny, A. M. M., Arafat, S. M., \& Kamel, S. M. (2013). Polyphenolic compounds of eggplant peel juice as a natural antioxidant for the stability of sunflower oil during deep-fat frying. Current Research in Microbiology and Biotechnology, 1, 1-8.

Benke, K. K., \& Benke, K. E. (2014). Experimental design issue for assessment of carotenoids lutein and zeaxanthin in age-related eye disease study 2 formulation for agerelated macular degeneration. JAMA Ophthalmology, 132, 904-905.

Blankemeyer, J. T., McWilliams, M. L., Rayburn, J. R., Weissenberg, M., \& Friedman, M. (1998). Developmental toxicology of solamargine and solasonine glycoalkaloids in frog embryos. Food And Chemical Toxicology, 36, 383-389.

Bohs, L., \& Weese, T. (2010). Eggplant origins: Out of Africa, into the Orient. Taxon, 59, 49-56.

Boulekbache-Makhlouf, B., Medouni, L., Medouni-Adrar, S., Arkoub, L, \& Madani, K. (2013). Effect of solvents extraction on phenolic content and antioxidant activity of the byproduct of eggplant. Industrial Crops and Products, 49, 668-674.

Casati, L., Pagani, F., Braga, P. C., Scalzo, R. L., \& Sibilia, V. (2016). Nasunin, a new player in the field of osteoblast protection against oxidative stress. Journal of Functional Foods, 23, 474-484.

Chataing, B., Concepción, J. L., Lobatón, R., \& Usubillaga, A. (1998). Inhibition of Trypanosoma cruzi growth in vitro by Solanum alkaloids: A comparison with ketoconazole. Planta Medica, 64, 31-36.

Chen, A. Y., \& Chen, Y. C. (2013). A review of the dietary flavonoid, kaempferol on human health and cancer chemoprevention. Food Chemistry, 138, 2099-2107.

Chumyam, A., Whangchai, K., Jungklang, J., Faiyue, B., \& Saengnil, K. (2013). Effects of heat treatments on antioxidant capacity and total phenolic content of four cultivars of purple skin eggplants. Science Asia, 39, 246.

Cichoż-Lach, H., \& Michalak, A. (2014). Oxidative stress as a crucial factor in liver diseases. World Journal of Gastroenterology, 20, 8082-8091.

Concellón, A., Zaro, M. J., Chaves, A. R., \& Vicente, A. R. (2012). Changes in quality and phenolic antioxidants in dark purple American eggplant (Solanum melongena L. cv. Lucía) as affected by storage at $0^{\circ} \mathrm{C}$ and $10^{\circ} \mathrm{C}$. Postharvest Biology and Technology, 66, 35-41.

Cooperstone, J. L., \& Schwartz, S. J. (2016). Recent insights into health benefits of carotenoids. Woodhead Publishing473-497.

Das, S., Raychaudhuri, U., Falchi, M., Bertelli, A., Braga, P. C., \& Das, D. K. (2011). Cardioprotective properties of raw and cooked eggplant (Solanum melongena L). Food and Function, 2, 395-399.

Ding, X., Zhu, F. S., Li, M., \& Gao, S. G. (2012). Induction of apoptosis in human hepatoma SMMC-7721 cells by solamargine from Solanum nigrum L. Journal of Ethnopharmacology, 139, 599-604.

Ding, X., Zhu, F., Yang, Y., \& Li, M. (2013). Purification, antitumor activity in vitro of steroidal glycoalkaloids from black nightshade (Solanum nigrum L.). Food Chemistry, $141,1181-1186$

Dogan, M., Arslan, O., \& Dogan, M. (2002). Substrate specificity, heat inactivation and inhibition of polyphenol oxidase from different aubergine cultivars. International Journal of Foof Science and Technology, 37, 415-423.

Dranca, F., \& Oroian, M. (2016). Optimization of ultrasound-assisted extraction of total 
monomeric anthocyanin (TMA) and total phenolic content (TPC) from eggplant (Solanum melongena L.) peel. Ultrasonics Sonochemistry, 32, 637-646.

Elekofehinti, O. O., Kamdem, J. P., Bolingon, A. A., Athayde, M. L., Lopes, S. R., Waczuk, E. P., Kade, I. J., Adanlawo, I. G., \& Rocha, J. B. T. (2013). African eggplant (Solanum anguivi Lam.) fruit with bioactive polyphenolic compounds exerts in vitro antioxidant properties and inhibits $\mathrm{Ca} 2+$ induced mitochondrial swelling. Asian Pacific Journal of Tropical Biomedicine, 3, 757-766.

El-Seedi, H. R., El-Said, A. M. A., Khalifa, S. A. M., Görensson, U., Bohlin, L., Borg-Karlson, A. K., \& Verpoorte, R. (2012). Biosynthesis, natural sources, dietary intake, pharmacokinetic properties, and biological activities of hydroxycinnamic acids. Journal of Agricultural and Food Chemistry, 60, 10877-10895.

Ferreira da Costa, G. A., Morais, M. G., Saldanha, A. A., Silva, I. C. A., Aleixo, A. A., Ferreira, J. M. S., Soares, A. C., Duarte-Almeida, J. M., \& Santos Lima, L. A. R. (2015). Antioxidant, antibacterial, cytotoxic, and anti-inflammatory potential of the leaves of Solanum lycocarpum A. St. Hil. (Solanaceae). Evidence-Based Complementary and Alternative Medicine (pp. 1-8). Food and Agriculture Organization of the United Nations http://fao.org. (Accessed 03.08.2017).

Fraikue, F. B (2016). Unveiling the potential utility of eggplant: A review, Conference Proceedings of INCEDI, pp. 883-895.

Friedman, M. (2006). Potato glycoalkaloids and metabolites: Roles in the plant and in the diet. Journal of Agricultural and Food Chemistry, 54, 8655-8681.

Gajewski, M., Katarzyna, K., \& Bajer, M. (2009). The influence of postharvest storage on quality characteristics of fruit of eggplant cultivars. Notulae Botanicae Horti Agrobotanici Cluj-Napoca, 37(2), 200-205.

García-Salas, P. G., Gómez-Caravaca, A. M., Gómez-Caravaca, A., Segura-Carretero, \& Fernández Gutiérrez, A. (2014). Identification and quantification of phenolic compounds in diverse cultivars of eggplant grown in different seasons by high-performance liquid chromatography coupled to diode array detector andelectrosprayquadrupole-time of flight-mass spectrometry. Food Research International, 57, $114-122$.

Ghosh, D., \& Konishi, T. (2007). Anthocyanins and anthocyanin-rich extracts: Role in diabetes and eye function. Asia Pacific Journal of Clinical Nutrition. 16(2), 200-208.

Gramazio, P., Blanca, J., Ziarsolo, P., Herraiz, F. J., Plazas, M., Prohens, J., \& Vilanova, S. (2016). Transcriptome analysis and molecular marker discovery in Solanum incanum and S. aethiopicum, two close relatives of the common eggplant (Solanum melongena) with interest for breeding. BMC Genomics, 17, 1-17.

Hall, C. A., Hobby, T., \& Cipollini, M. (2006). Efficacy and mechanisms of $\alpha$-solasonine and $\alpha$-solamargine-induced cytolysis on two strains of Trypanosoma cruzi. Journal of Chemical Ecology, 32, 2405-2416.

Hanson, P. M., Yang, R. Y., Tsou, S. C. S., Ledesma, D., Engle, L., \& Lee, T. C. (2006). Diversity in eggplant (Solanum melongena) for superoxide scavenging activity, total phenolics, and ascorbic acid. Journal of Food Composition and Analysis, 19, 594-600.

Helmja, K., Vaher, M., Gorbatšova, J., \& Kaljurand, M. (2007). Characterization of bioactive compounds ontained in vegetables of the Solanaceae family by capillary electrophoresis. Proceedings of the Estonian Academy of Sciences, 56, 172-186.

Hernandez-Hernandez, O. H., Ruiz-Aceituno, L., Sanz, M. L., \& Martínez-Castro, I. (2011). Determination of free inositols and other low molecular weight carbohydrates in vegetables. Journal of Agricultural and Food Chemistry, 59, 2451-2455.

Huang, Z., Wang, B., Eaves, D. H., Shikany, J. M., \& Pace, R. D. (2007). Phenolic compound profile of selected vegetables frequently consumed by African Americans in the southeast United States. Food Chemistry, 103, 1395-1402.

Hussein, E. A. (2012). Potential therapeutic effects of dried cabbage and eggplant on hypercholestromic rat. Nutrition and Food Science, Faculty of Home Economics, Minofiya University1770-1784.

Im, K., Lee, J. Y., Byeon, H., Hwang, K. W., Kang, W., Whang, W. K., \& Min, H. (2016). In Vitro antioxidative and anti-inflammatory activities of the ethanol extract of eggplant (Solanum melongena) stalks in macrophage RAW 264.7 cells. Food and Agricultural Immunology, 27, 758-771.

Jan, A. T., Kamli, M. R., Murtaza, I., Singh, J. B., \& Ali, A. (2010). Dietary flavonoid quercetin and associated health benefits-an overview. Food Reviews International, 26, 302-317.

Jaramillo, S., Lopez, S., Verale, L. M., Arcos, R. R., Jimenez, A., Abia, R., \& Muriana, F. J. G. (2010). The flavonol isorhamnetin exhibits cytotoxic effects on human colon cancer cells. Journal of Agricultural and Food Chemistry, 16, 3035-3042.

Jiang, D., Li, D., \& Wu, W. (2013). Inhibitory effects and mechanisms of luteolin on proliferation and migration of vascular smooth muscle cells. Nutrients, 5, 1648-1659.

Kalkan, I., \& Yücecan, S. (2013). Stability of dietary phenolics and antioxidant properties of vegetables depends on cooking methodology. Müsbed, 3, 8-16.

Kamga, R. T., Kouame, C., Atangana, A. R., Chagomoka, T., \& Ndango, R. (2013). Nutritional evaluation of five african indigenous vegetables. Journal of Horticultural Research, 21, 99-106.

Kaneyuki, T., Noda, Y., Traber, M. G., Mori, A., \& Packer, L. (1999). Superoxide anion and hydroxyl radical scavenging activities of vegetable extracts measured using electron spin resonance. Biochemistry and Molecular Biology International, 47, 979-989.

Kaur, C., Nagal, S., Nishad, J., Kumar, R., \& Sarika (2014). Evaluating eggplant (Solanum melongena L) genotypes for bioactive properties: A chemometric approach. Food Research International, 60, 205-211.

Kliebenstein, D. (2009). Advancing genetic theory and application by metabolic quantitative trait loci analysis. Plant Cell, 21, 1637-1646.

Kumari, M., \& Jain, S. (2012). Tannin: An antinutrient with positive effect to manage diabetes. Research Journal of Recent Sciences, 1, 1-8.

Lezama-Dávila, C. M., McChesney, J. D., Bastos, J. K., Miranda, M. A., Tiossi, R. F., da Costa, J. C., \& Isaac-Márquez, A. P. (2016). A new antileishmanial preparation of combined solamargine and solasonine heals cutaneous leishmaniasis through different immunochemical pathways. Antimicrobial Agents and Chemotherapy, 60, 2732-2738.

Li, Y., \& Ding, Y. (2012). Minireview: Therapeutic potential of myricetin in diabetes mellitus. Food Science and Human Wellness, 1, 19-25.

Li, X., Zhao, Y., Ji, M., Liu, S. S., Cui, M., \& Lou, H. X. (2011). Induction of actin disruption and downregulation of P-glycoprotein expression by solamargine in multidrug-resistant K562/A02 cells. Chinese Medical Journal, 124, 2038-2044.

Lin, W., \& Li, Z. (2017). Blueberries inhibit cyclooxygenase-1 and cyclooxygenase-2 activity in human epithelial ovarian cancer. Oncology Letters, 4897-4904.

Linnewiel-Hermoni, K., Khanin, M., Danilenko, M., Zango, G., Amosi, Y., Levy, J., \& Sharoni, Y. (2015). The anti-cancer effects of carotenoids and other phytonutrients resides in their combined activity. Archives of Biochemistry and Biophysics, 572, 28-35.

Liu, L. F., Liang, C. H., Shiu, L. Y., Lin, W. L., Lin, C. C., \& Kuo, K. W. (2004). Action of solamargine on human lung cancer cells - Enhancement of the susceptibility of cancer cells to TNFs. FEBS Letters, 577, 67-74.

Lobo, V., Phatak, A., \& Chandra, N. (2010). Free radicals, antioxidants and functional foods: Impact on human health. Pharmacognosy Reviews, 4, 118-126.

Lorenzo, Y., Azqueta, A., Luna, L., Bonilla, F., Dominguez, G., \& Collins, A. R. (2009). The carotenoid beta-cryptoxanthin stimulates the repair of DNA oxidation damage in addition to acting as an antioxidant in human cells. Carcinogenesis, 30, 308-314.

Luthria, D., Singh, A. P., Wilson, T., Vorsa, N., Banuelos, G. S., \& Vinyard, B. T. (2010). Influence of conventional and organic agricultural practices on the phenolic content in eggplant pulp: Plant-to-plant variation. Food Chemistry, 121, 406-411.

Macha, E.S. (2005). African eggplants promising vegetables for home consumption and sale in Tanzania. In Proceedings of the Third Horticulture Workshop on Sustainable Horticultural Production in the Tropics, Maseno, Kenya.

Maloney, V. (2004). Plant metabolomics. Biotechnology Journal, 4, 92-99.

Manikandan, R., Thiagarajan, R., Goutham, G., Arumugam, M., Beulaja, M., Rastrelli, L., \& Orhan, I. E. (2016). Zeaxanthin and ocular health, from bench to bedside. Fitoterapia, 109, 58-66.

Matsubara, K., Kaneyuki, T., Miyake, T., \& Mori, M. (2005). Antiangiogenic activity of nasunin, an antioxidant anthocyanin, in eggplant peels. Journal of Agricultural and Food Chemistry, 53, 6272-6275.

Medina, M. G., Rangel, D. M., Bejar, A. G., Aguilar, G. G., Heredia, B., Sanudo, M. B., \& Rocha, V. L. (2014). Nutritional and nutraceutical components of commercial eggplant types grown in Sinaloa, Mexico. Notulae Botanicae Horti Agrobotanici ClujNapoca, 42, 538-544.

Medina, G. N., Orona, V. U., Rangel, M. D., \& Heredia, J. B. (2017). Structure and content of phenolics in eggplant (Solanum melongena) - A review. South African Journal of Botany, 111, 161-169.

Mei, X., Yi, C., \& Huang, G. (2017). The antioxidant activities of polysaccharides and their derivatives. Current Drug Targets, 18(11), 1296-1300.

Mennella, G., Lo Scalzo, R., Fibiani, M., D'Alessandro, A., Francese, G., Toppino, L., \& Rotino, G. L. (2012). Chemical and bioactive quality traits during fruit ripening in eggplant (S. melongena L.) and allied species. Journal of Agricultural and Food Chemistry, 60, 11821-11831.

Meyer, R. S., Bamshad, M., Fuller, D. Q., \& Litt, A. (2014). Comparing medicinal uses of eggplant and related Solanaceae in China, India, and the Philippines suggests the independent development of uses, cultural diffusion, and recent species substitutions. Economic Botany, 1-16.

Meyer, R. S., Karol, K. G., Little, D. P., Nee, M. H., \& Litt, A. (2012). Phylogeographic relationships among Asian eggplants and new perspectives on eggplant domestication. Molecular Phylogenetics and Evolution, 63, 685-701.

Mibei, E. K., Ambuko, J., Giovannoni, J. J., Onyango, A. N., \& Owino, W. O. (2017). Carotenoid profiling of the leaves of selected African eggplant accessions subjected to drought stress. Food Science and Nutrition, 5, 113-122.

Michell, R. (2007). Evolution of the diverse biological roles of inositols. Biochemical Society Symposia, 74, 223-246.

Miranda, M. A., Tiossi, R. F. J., da Silva, M. R., Rodrigues, K. C., Kuehn, C. C., Oliveira, L. G. R., \& Bastos, J. K. (2013). In vitro leishmanicidal and cytotoxic activities of the glycoalkaloids from Solanum lycocarpum (Solanaceae) fruits. Chemistry \& Biodiversity, 10, 642-648.

Mishra, B. B., Gautam, S., \& Sharma, A. (2012). Browning of fresh-cut eggplant: Impact of cutting and storage. Postharvest Biology and Technology, 67, 44-51.

Mishra, B. B., Gautam, S., \& Sharma, A. (2013). Free phenolics and polyphenol oxidase (PPO): The factors affecting post-cut browning in eggplant (Solanum melongena). Food Chemistry, 139, 105-114.

Morales-Soto, A., García-Salas, P., Rodríguez-Pérez, C., Jiménez-Sánchez, C., CádizGurrea, M. L., Segura-Carretero, A., \& Fernández-Gutiérrez, A. (2014). Antioxidant capacity of 44 cultivars of fruits and vegetables grown in Andalusia (Spain). Food Research International, 58, 35-46.

Murcia, A., Jiménez, A., \& Martínez-Tomé, M. (2009). Vegetables antioxidant losses during industrial processing and refrigerated storage. Food Research International, 42, 1046-1052.

Nisha, P., Nazar, P. A., \& Jayamurthy, P. (2009). A comparative study on antioxidant activities of different varieties of Solanum melongena. Food and Chemical Toxicology, 47, 2640-2644.

Nwanna, E. E., Ibukun, E. O., \& Oboh, G. (2013). Inhibitory effects of methanolic extracts of two eggplant species from South-western Nigeria on starch hydrolysing enzymes linked to type-2 diabetes. African Journal of Pharmacy and Pharmacology, 7, $1575-1584$.

Nwanna, E. E., Ibukun, E. O., \& Oboh, G. (2016). Effect of some tropical eggplant fruits (Solanum Spp) supplemented diet on diabetic neuropathy in male Wistar rats in vivo. Functional Foods in Health and Disease, 6, 661-676.

Okmen, B., Sigva, H. O., Mutlu, S., Doganlar, S., Yemenicioglu, A., \& Frary, A. (2009). Total antioxidant activity and total phenolic contents in different Turkish eggplant (Solanum Melongena L.) cultivars. International Journal of Food Properties, 12, 616-624.

Ossamulu, I. F., Akanya, H. O., Jigam, A. A., \& Egwim, E. C. (2014). Evaluation of nutrient 
and phytochemical constituents of four eggplant cultivars. Food Science, 73, 26424-26428.

Piao, X. M., Chung, J. W., Lee, G. A., Lee, J. R., Cho, G. T., Lee, H. S., \& Lee, H. S. (2014). Variation in antioxidant activity and flavonoid aglycones in eggplant (Solanum melongena L.) germplasm. Plant Breeding and Biotechnology, 2, 396-403.

Pietro, N. D., Tomo, P. D., \& Pandolfi, A. (2016). Carotenoids in cardiovascular disease prevention. JSM Atherosclerosis, 1, 1-13.

Plazas, M., Andujar, I., Vilanova, S., Hurtado, M., Gramazio, P., Herraiz, F., \& Prohens, J. (2013). Breeding for chlorogenic acid content in eggplant: Interest and prospects. Notulae Botanicae Horti Agrobotanici Cluj-Napoca, 41, 26-35.

Plazas, M., Lopez-Gresa, M. P., Vilanova, S., Torres, C., Hurtado, M., Gramazio, P., \& Prohens, J. (2013). Diversity and relationships in key traits for functional and apparent quality in a collection of eggplant: Fruit phenolics content, antioxidant activity, polyphenol oxidase activity, and browning. Journal of Agricultural and Food Chemistry, 61, 8871-8879.

Prohens, J., Whitaker, B. D., Plazas, M., Vilanova, S., Hurtado, M., Blasco, M., \& Stommel, J. R. (2013). Genetic diversity in morphological characters and phenolic acids content resulting from an interspecific cross between eggplant, Solanum melongena, and its wild ancestor (S. incanum). Annals of Applied Biology, 162, 242-257.

Prohens, J., Burruezo, A. R., Raigon, M. D., \& Nuez, F. (2007). Total phenolic concentration and browning susceptibility in a collection of different varietal types and hybrids of eggplant: Implications for breeding for higher nutritional quality and reduced browning. Journal of the American Society for Horticultural Science. 132, 638-646.

Punjabi, S., Cook, L. J., Kersey, P., Marks, R., \& Cerio, R. (2008). Solasodine glycoalkaloids: A novel topical therapy for basal cell carcinoma. A double-blind, randomized, placebo-controlled, parallel group, multicenter study. International Journal of Dermatology. 2008(47), 78-82.

Raigon, M. D., Prohens, J., Muñoz-Falcón, J. E., \& Nuez, F. (2008). Comparison of eggplant landraces and commercial varieties for fruit content of phenolics, minerals, dry matter and protein. Journal of Food Composition and Analysis, 21, 370-376.

Raigon, M. D., Rodriguez-Burruezo, A., \& Prohens, J. (2010). Effects of organic and conventional cultivation methods on composition of eggplant fruits. Journal of Agricultural and Food Chemistry, 58, 6833-6840.

Ramírez-Anaya, J. P., Samaniego-Sánchez, C., Castañeda-Saucedo, C., Villalón-Mir, M., \& Serrana, H. L. G. (2015). Phenols and the antioxidant capacity of Mediterranean vegetables prepared with extra virgin olive oil using different domestic cooking techniques. Food Chemistry, 188, 430-438.

Sanchez-Maldonado, A. F., Schieber, A., \& Gänzle, M. G. (2016). Antifungal activity of secondary plant metabolites from potatoes (Solanum tuberosum L.): Glycoalkaloids and phenolic acids show synergistic effects. Journal of Applied Microbiology, 120, 955-965.

Sanchez-Mata, M. C., Yokoyama, W. E., Hong, Y. J., \& Prohens, J. (2010). Alpha-solasonine and alpha-solamargine contents of gboma (Solanum macrocarpon L.) and scarlet (Solanum aethiopicum L.) eggplants. Journal of Agricultural and Food Chemistry, $58,5502-5508$

Seeram, N. P., Momin, R. A., Nair, M. G., \& Bourquin, L. D. (2001). Cyclooxygenase inhibitory and antioxidant cyanidin glycosides in cherries and berries. Phytomedicine, 8, 362-369.

Shen, K. H., Hung, J. H., Chang, C. W., Weng, Y. T., Wu, M. J., \& Chen, P. S. (2017). Solasodine inhibits invasion of human lung cancer cell through downregulation of miR-21 and MMPs expression. Chemico-Biological Interactions, 268, 129-135.

Singh, J. P., Kaur, A., Shevkani, K., \& Singh, N. (2015). Influence of jambolan (Syzygium cumini) and xanthan gum incorporation on the physicochemical, antioxidant and sensory properties of gluten-free eggless rice muffins. Food Science and Technology, 50, 1190-1197.

Stommel, J. R., Whitaker, B. D., Haynes, K. G., \& Prohens, J. (2015). Genotype $\times$ en vironment interactions in eggplant for fruit phenolic acid content. Euphytica, 205, 823-836.

Sun, L., Zhao, Y., Yuan, H., Li, X., Cheng, A., \& Lou, H. (2011). Solamargine, a steroidal alkaloid glycoside, induces oncosis in human K562 leukemia and squamous cell carcinoma KB cells. Cancer Chemotherapy and Pharmacology, 67, 813-821.

Syfert, M. M., Castaneda-Alvarez, N. P., Khoury, C. K., Särkinen, T., Sosa, C. C., Achicanoy, H. A., \& Knapp, S. (2016). Crop wild relatives of the brinjal eggplant (Solanum melongena): Poorly represented in genebanks and many species at risk of extinction. American Journal of Botany, 103, 635-651.

Swarup, V. (1995). Genetic resources and breeding of aubergine (Solanum melongena L.). In R. Fernández-Muñoz, J. Cuartero, M. L. Gómez-Guillamón (Eds.), International Symposium on Solanacea for Fresh Market, Malaga, Spain (pp. 71-79).

Tajik, N., Tajik, M., Mack, I., \& Enck, P. (2017). The potential effects of chlorogenic acid, the main phenolic components in coffee, on health: A comprehensive review of the literature. European Journal of Nutrition, 56, 2215-2244.

Tan, S. P., Kha, T. C., Parks, S. E., \& Roach, P. D. (2016). Bitter melon (Momordica charantia L.) bioactive composition and health benefits: A review. Food Reviews International, 32, 181-202.

Trisat, K., Wong, M., Lapphanichayakool, P., Tiyaboonchai, W., \& Limpeanchob, N. (2017). Vegetable juices and fibers reduce lipid digestion or absorption by inhibiting pancreatic lipase, cholesterol solubility and bile acid binding. International Journal of Vegetable Science, 23, 260-269.

Uchida, K., Tomita, H., Takemori, T., \& Takamura, H. (2017). Effects of grilling on tota polyphenol content and antioxidant capacity of eggplant (Solanum melongena L.). Journal of Food Science, 82, 202-207.

van Lent, D. M., Leermakers, E. T. M., Darweesh, S. K. L., Moreira, E. M., Tielemans, M. J., Muka, T., \& Franco, O. H. (2016). The effects of lutein on respiratory health across the life course: A systematic review. Clinical Nutrition ESPEN, 13, 1-7.

Yousuf, B., Gul, K., Wani, A. A., \& Singh, P. (2016). Health benefits of anthocyanins and their encapsulation for potential use in food systems: A review. Critical Reviews in Food Science and Nutrition, 56, 2223-2230.

Wang, L. S., \& Stoner, G. D. (2008). Anthocyanins and their role in cancer prevention. Cancer Letters, 269, 281-290.

Watson, R. R., \& Schönlau, F. (2015). Nutraceutical and antioxidant effects of a delphinidin-rich maqui berry extract Delphinol: A review. Minerva Cardioangiologica, 63, $1-12$.

Weikel, K. A., Garber, C., Baburins, A., \& Taylor, A. (2014). Nutritional modulation of cataract. Nutrition Reviews, 72, 30-47.

Whitaker, B. D., \& Stommel, J. R. (2003). Distribution of hydroxycinnamic acid conjugates in fruit commercial eggplant (Solanum melongena L.) cultivars. Journal of Agricultural and Food Chemistry, 51, 3448-3454.

Zambrano-Moreno, E. L., Chávez-Jáuregui, R. N., Plaza, M. L., \& Beaver, L. W. (2015). Phenolic content and antioxidant capacity in organically and conventionally grown eggplant (Solanum melongena) fruits following thermal processing. Food Science and Technology, 35, 414-420.

Zaro, M. J., Keunchkarian, S., Chaves, A. R., Vicente, A. R., \& Concellón, A. (2014). Changes in bioactive compounds and response to postharvest storage conditions in purple eggplants as affected by fruit developmental stage. Postharvest Biology and Technology, 96, 110-117. 